\title{
VARIATIONS IN THE SENSITIVITY OF DIFFERENT PRIMERS FOR DETECTING WOLBACHIA IN ANASTREPHA (DIPTERA: TEPHRITIDAE)
}

\author{
Helena Sanches Marcon ${ }^{1 *}$, Virgínia Elias Coscrato ${ }^{1}$, Denise Selivon ${ }^{2}$, André Luiz Paranhos Perondini², Celso Luis Marino ${ }^{1}$ \\ ${ }^{1}$ Departamento de Genética, Instituto de Biociências, Universidade Estadual Paulista Júlio de Mesquita Filho, Botucatu, SP, \\ Brasil; ${ }^{2}$ Departamento de Genética e Biologia Evolutiva, Instituto de Biociências, Universidade de São Paulo, São Paulo, SP, \\ Brasil.
}

Submitted: May 02, 2010; Returned to authors for corrections: August 23, 2010; Approved: January 13, 2011.

\begin{abstract}
Wolbachia are endosymbiont bacteria of the family Rickettsiacea that are widespread in invertebrates and occur between $20 \%$ and $60 \%$ of Neotropical insects. These bacteria are responsible for reproductive phenomena such as cytoplasmic incompatibility, male killing, feminization and parthenogenesis. Supergroups A and B of Wolbachia are common in insects and can be identified using primers for $16 \mathrm{~S}$ rDNA, ftsZ and wsp; these primers vary in their ability to detect Wolbachia. The ftsZ primer was the first primer used to detect Wolbachia in Anastrepha fruit flies. The primers for 16S rDNA, ftsZ and wsp and the corresponding PCR conditions have been optimized to study the distribution of Wolbachia and their effect on the biology of Anastrepha in Brazil. In this work, we examined the ability of these primers to detect Wolbachia in Anastrepha populations from three regions in the State of São Paulo, southeastern Brazil. All of the samples were positive for Wolbachia supergroup A when screened with primers for 16S A rDNA and wsp A; the wsp B primer also gave a positive result, indicating cross-reactivity. The fts $\mathrm{Z}$ primer showed a poor ability to detect Wolbachia in Anastrepha and generated false negatives in $44.9 \%$ of the samples. These findings indicate that reliable PCR detection of Wolbachia requires the use of primers for 16S rDNA and $w s p$ to avoid cross-reactions and false negatives, and that the fts $\mathrm{Z}$ primer needs to be redesigned to improve its selectivity.
\end{abstract}

Key words: Anastrepha, cross reaction, ftsZ, wsp

\section{INTRODUCTION}

Wolbachia are intracellular obligatory bacteria of the family Rickettsiacea that occur in a wide range of arthropods and nematodes. These bacteria are maternally inherited by horizontal transmission $(26,29)$ and enhance their propagation by altering the reproductive system of their host in various ways, e.g., by cytoplasmic incompatibility, male killing, feminization and parthenogenesis $(19,24)$.

Molecular markers have been extensively used to detect Wolbachia. For example, primers for 16S rDNA (a ribosomal gene), ftsZ (a regulatory gene of the bacterial cell cycle) and 
wsp (a gene for an cell membrane protein) have been used to study the phylogenetics of Wolbachia $(2,6,18)$ and have led to the division of Wolbachia into eight taxonomic supergroups (A to $H)(12,13,27)$. The initial studies in this field were done with $16 \mathrm{~S}$ rDNA primers and identified two groups, A and B, that diverged about 50 million years ago and are widely distributed in insects $(14,27)$.

The fts $Z$ gene was extensively used by Werren and colleagues $(27,28)$ to detect Wolbachia, but several studies have demonstrated its low sensitivity $(3,9,30,31)$. This low sensitivity can lead to false negatives in bacterial detection when this primer is used alone, i.e., without another marker or technique to detect Wolbachia. The $16 \mathrm{~S}$ and wsp primers have greater sensitivity for detecting Wolbachia $(30,31)$, although the $w s p$ primer can generate false positives in discriminating between supergroups A and B (8). This lack of absolute specificity means that there is a need to use specific primers in the characterization of these bacteria.

Between $20 \%$ and $60 \%$ of Neotropical insects are infected with Wolbachia (28). Studies in different regions of Brazil have detected Wolbachia in fruit flies of the genus Anastrepha (3, 4, 17, 23). Anastrepha fruit flies are a major pest insect of Brazilian fruit crops because of the losses they cause to commercial fruit growers $(5,15)$. The presence of Wolbachia in Anastrepha is therefore of considerable interest since these bacteria may be exploited as biological controls of pest insects, as suggested by Bourtzis (1).

Coscrato (4) and Mascarenhas (17) showed that 16S and wsp primers varied in their ability to detect Wolbachia in different Anastrepha species; studies with other fruit fly genera, such as Bactrocera $(8,11,25)$, Rhagoletis cerasi (20) and Ceratitis capitata (21), have reported similar findings. In this work, we examined the ability of $16 \mathrm{~S}$, ftsZ and wsp primers to detect Wolbachia in populations of Anastrepha from different regions of the State of São Paulo in southeastern Brazil.

\section{MATERIALS AND METHODS}

Sixty-six fruit fly larvae collected from guava (Psidium guajava) and chapeu-do-sol (Terminalia catappa) fruits in three regions of the State of São Paulo, southeastern Brazil (Table 1), were stored in boxes with vermiculite and transported to the laboratory, where the larvae were allowed to develop to pupal stage. The pupae were subsequently removed and allowed to grow to the adult stage for species identification, after which they were stored in $70 \%$ ethanol at $20^{\circ} \mathrm{C}$.

Table 1. Number of individuals, host plants, collection sites and geographic location of the fruit fly populations examined in this study. All collection sites were in the State of São Paulo.

\begin{tabular}{|c|c|c|c|c|c|}
\hline Taxon & Species & $\begin{array}{c}\text { No. of } \\
\text { individuals }\end{array}$ & Host plant & Collection site & Geographic location \\
\hline \multirow{4}{*}{ fraterculus } & A. sp. 1 aff. fraterculus & 11 & $\begin{array}{c}\text { Guava } \\
\text { (Psidium guajava) }\end{array}$ & Jacareí & $23^{\circ} 17^{\prime} \mathrm{S} ; 46^{\circ} 01^{\prime} \mathrm{W}$ \\
\hline & A. sp. 1 aff. fraterculus & 19 & $\begin{array}{c}\text { Guava } \\
(\text { Psidium guajava })\end{array}$ & Serra Negra & $22^{\circ} 35^{\prime} \mathrm{S} ; 46^{\circ} 50^{\prime} \mathrm{W}$ \\
\hline & A. sp.2 aff. fraterculus & 21 & $\begin{array}{c}\text { Chapéu-do-sol } \\
\text { (Terminalia catappa) }\end{array}$ & Caraguatatuba & $23^{\circ} 39^{\prime} \mathrm{S} ; 45^{\circ} 25^{\prime} \mathrm{W}$ \\
\hline & A. sp. 3 aff. fraterculus & 24 & $\begin{array}{c}\text { Chapéu-do-sol } \\
\text { (Terminalia catappa) }\end{array}$ & & \\
\hline
\end{tabular}


DNA was extracted from each fly abdomen using the protocol described by Jowett (10), with some modifications. Amplification reactions were done as described below.

The reaction mixture for the wsp $\mathrm{A}$ and $\mathrm{B}$ primers consisted of $50 \mathrm{ng}$ of DNA, $10 \mathrm{X}$ buffer (Invitrogen), $1.0 \mu \mathrm{l}$ of $50 \mathrm{mM} \mathrm{MgCl}_{2}, 0.4 \mu \mathrm{l}$ of dNTPs $(10 \mu \mathrm{M}$ each), $0.5 \mu \mathrm{l}$ of forward $(\mathrm{F})$ primer $(20 \mu \mathrm{M}), 0.5 \mu \mathrm{l}$ of reverse $(\mathrm{R})$ primer $(20$

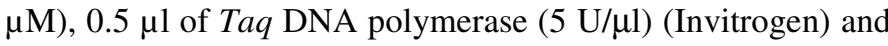
water in a final volume of $20 \mu$ l. The amplification reaction consisted of one cycle of $1 \mathrm{~min}$ at $94^{\circ} \mathrm{C}, 1 \mathrm{~min}$ at $58^{\circ} \mathrm{C}$ and 2 min at $72^{\circ} \mathrm{C}$, followed by 35 cycles of $15 \mathrm{~s}$ at $94^{\circ} \mathrm{C}, 1 \mathrm{~min}$ at $58^{\circ} \mathrm{C}$ and $2 \mathrm{~min}$ at $72^{\circ} \mathrm{C}$, and one cycle of $15 \mathrm{~s}$ at $94^{\circ} \mathrm{C}, 1 \mathrm{~min}$ at $58^{\circ} \mathrm{C}$ and $7 \mathrm{~min}$ at $72^{\circ} \mathrm{C}$. These conditions yielded PCR products of $\sim 600$ base pairs (bp) $(2,32)$.

The reaction mixture for the fts $\mathrm{Z} \mathrm{A}$ and $\mathrm{B}$ primers (6) consisted of $50 \mathrm{ng}$ of DNA, $10 \mathrm{X}$ buffer (Invitrogen), $0.6 \mu \mathrm{l}$ of $50 \mathrm{mM} \mathrm{MgCl} 2,0.4 \mu \mathrm{l}$ of dNTPs $(10 \mu \mathrm{M}$ each $), 0.5 \mu \mathrm{l}$ of $\mathrm{F}$ primer $(10 \mu \mathrm{M}), 0.5 \mu \mathrm{l}$ of $\mathrm{R}$ primer $(10 \mu \mathrm{M}), 0.5 \mu \mathrm{l}$ of Taq DNA polymerase $(5 \mathrm{U} / \mu \mathrm{l})$ (Invitrogen) and water in a final volume of $20 \mu \mathrm{l}$. The amplification reaction consisted of an initial 4 min incubation at $94^{\circ} \mathrm{C}$, followed by one cycle of 1 min at $58^{\circ} \mathrm{C}$ and $2 \mathrm{~min}$ at $72^{\circ} \mathrm{C}, 38$ cycles of $15 \mathrm{~s}$ at $94^{\circ} \mathrm{C}, 1 \mathrm{~min}$ of $58^{\circ} \mathrm{C}$ and $2 \mathrm{~min}$ at $72^{\circ} \mathrm{C}$, one cycle of $15 \mathrm{~s}$ at $94^{\circ} \mathrm{C}$ and $1 \mathrm{~min}$ at $58^{\circ} \mathrm{C}$, with a final extension of $7 \mathrm{~min}$ at $72^{\circ} \mathrm{C}$. These conditions yielded fragments of 1043-1055 bp.

The reaction mixture for the $16 \mathrm{~S} \mathrm{~A}$ and $\mathrm{B}$ rDNA primers (18) consisted of $50 \mathrm{ng}$ of DNA, 10X buffer (Invitrogen), 0.75 $\mu \mathrm{l}$ of $50 \mathrm{mM} \mathrm{MgCl}, 0.5 \mu \mathrm{l}$ of dNTPs (10 $\mu \mathrm{M}$ each), $0.35 \mu \mathrm{l}$ of F primer $(20 \mu \mathrm{M}), 0.35 \mu \mathrm{l}$ of $\mathrm{R}$ primer $(20 \mu \mathrm{M}), 0.25 \mu \mathrm{l}$ of $\mathrm{Taq}$ DNA polymerase $(5 \mathrm{U} / \mu \mathrm{l})$ (Invitrogen) and water in a final volume of $25 \mu \mathrm{l}$. The amplification reaction consisted initially of $2 \mathrm{~min}$ at $95^{\circ} \mathrm{C}, 35$ cycles of $30 \mathrm{~s}$ at $95^{\circ} \mathrm{C}, 1 \mathrm{~min}$ at $55^{\circ} \mathrm{C}$ and 1 $\min$ at $72^{\circ} \mathrm{C}$, with a final extension of $3 \mathrm{~min}$ at $72^{\circ} \mathrm{C}$. These conditions yielded fragments of $\sim 259 \mathrm{bp}$.

In all cases, the PCR products were analyzed by electrophoresis in 1\% agarose gels in Tris-borate EDTA buffer (TBE 1X) containing $1 \%$ ethidium bromide. After electrophoresis, the gels were examined in ultraviolet light and documented with an Eagle Eye II photodocumentation system (Stratagene).

For sequencing, the PCR products were purified with $\mathrm{GFX}^{\mathrm{TM}}$ PCR DNA and gel band purification kits (Amersham Pharmacia Biotech), after which DNA (100 ng/ $\mu \mathrm{l})$ was mixed with $1.0 \mu$ of buffer (1 M Tris-HCl, pH 9.0, containing $50 \mathrm{mM}$ $\mathrm{MgCl}_{2}$ ), $2.0 \mu \mathrm{l}$ of Big Dye, $1.0 \mu \mathrm{l}$ of primer ( $\left.5 \mathrm{pmol} / \mathrm{ul}\right)$ and water in a final volume of $10 \mu \mathrm{l}$. Sequencing was done in a Genetic Analyzer 3100 (Applied Biosystems) sequencer. The sequences generated from these samples and the corresponding consensus sequences were assembled with phredPhrap/consed v. 14.0 and then used to search the National Center for Biotechnology Information (NCBI) database for homology with Wolbachia sequences; the searches were done using BLASTN (http://www.ncbi.nlm.nih.gov).

\section{RESULTS AND DISCUSSION}

Wolbachia was detected in all of the DNA fragments generated by the $16 \mathrm{~S}$ and wsp primers in Anastrepha species 1, 2 and 3 . The sequence of the DNA fragment amplified with the wsp primer showed $98 \%$ and $96 \%$ similarity with Wolbachia from Anastrepha sp.2 aff. fraterculus (EU116316.1) and Wolbachia from Brugia pahangi (AY527208.1), respectively. The results with the 16S rDNA and wsp primers allowed us to classify the bacteria as belonging to Wolbachia supergroup A. These results were similar to studies in other Anastrepha species $(4,17)$.

In some samples, the wsp B primer generated fragments that suggested the presence of supergroup B (figure 1A). However, this result was considered to be a false positive since no fragments were generated by the primer for $16 \mathrm{~S}$ B rDNA (figure 1B). Kittayapong (11) and Ruang-Areerate (22) have previously shown that the wsp B primer yields false positive results for this Wolbachia supergroup because of crossreactions; similar findings have been described by Coscrato (3) and Marcon (16). Together, these studies indicate that the 
conclusive identification of Wolbachia supergroup A in Anastrepha requires the use of wsp and 16S rDNA primers.

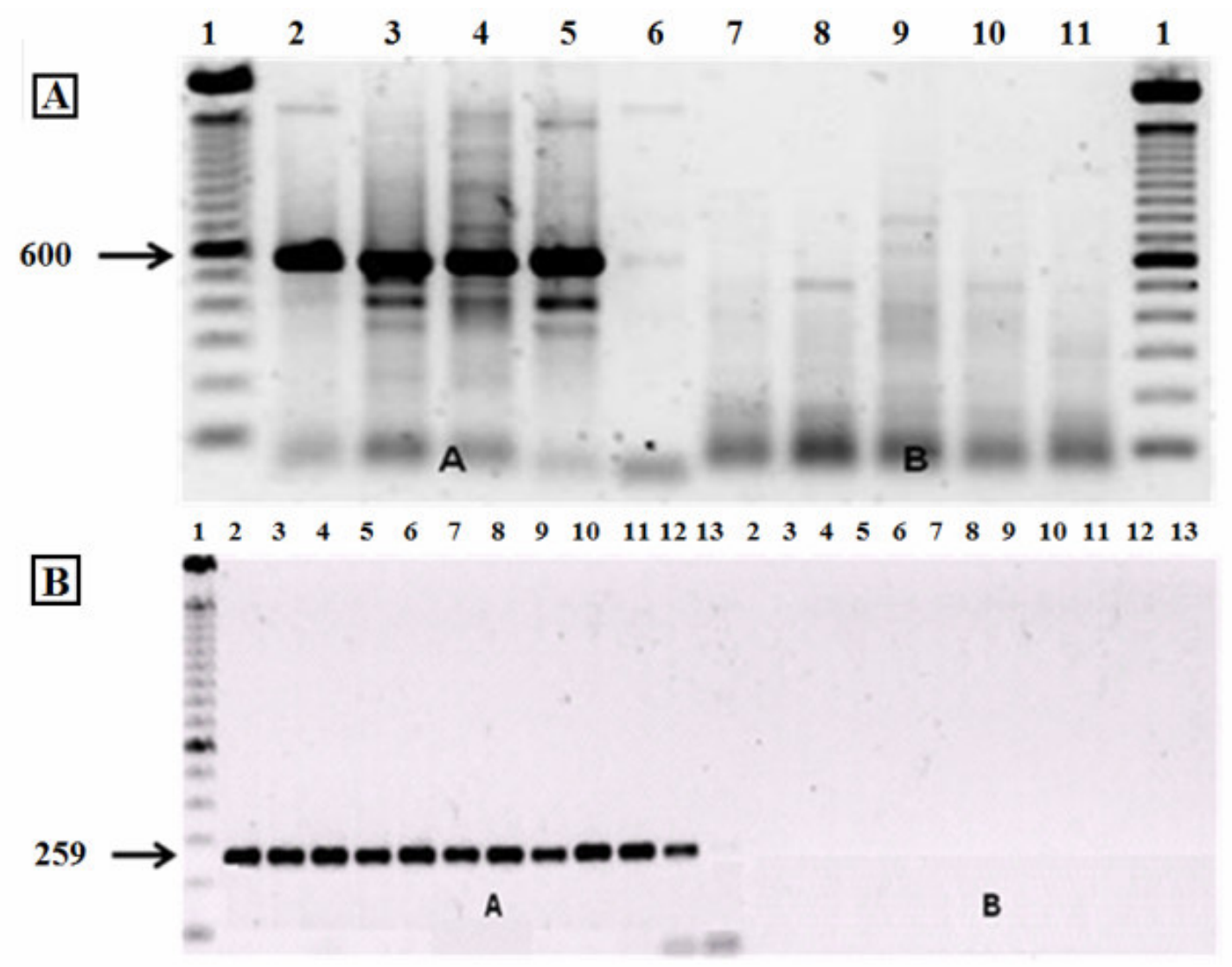

Figure 1. Electrophoresis of Anastrepha sp.1 samples in 1\% agarose gels containing 1\% ethidium bromide, after amplification. In (A), the primers used were wsp $\mathrm{A}$ in lanes $2 \mathrm{~A}-6 \mathrm{~A}$ and $w s p \mathrm{~B}$ in lanes $7 \mathrm{~B}-11 \mathrm{~B}$. In (B), the primers used were for $16 \mathrm{~S} \mathrm{~A}$ rDNA in lanes $2 \mathrm{~A}-13 \mathrm{~A}$ and $16 \mathrm{~S} \mathrm{~B}$ rDNA in lanes 2B-13B.

We also compared the results obtained for the $f t s \mathrm{Z}$ primer with those for the $16 \mathrm{~S}$ and $w s p$ primers, particularly since data generated by the former primer have sometimes led to the misidentification of Wolbachia. No Wolbachia were detected in the 66 samples incubated with the ftsZ primer, a finding in agreement with previous studies that have also used this primer to screen for these bacteria in other insects $(7,9,30)$.

The $f t s Z$ gene is of particular importance because of the potential usefulness of its product for detecting Wolbachia, identifying supergroups and performing phylogenetic analyses. We therefore sought to optimize the PCR protocol for this primer by altering the concentrations of DNA, $\mathrm{MgCl}_{2}$, dNTPs, primers and Taq DNA polymerase and quality of the DNA in order to detect Wolbachia in Anastrepha (Table 2). When the volume of DNA in the reaction was decreased to $3 \mu$ (50 ng/ul), Walbachia was detected in $27 \%$ of Anastrepha sp.1 (Jacareí) samples (Table 3). Based on these results, this volume of DNA was used in subsequent reactions. 
Table 2. Modifications in the reagent concentrations and volumes of the PCR reactions (ftsZ I-VIII) used to detect Wolbachia in Anastrepha with the ftsZ primer.

\begin{tabular}{|c|c|c|c|}
\hline PCR reaction & Reagents & Concentration & Volume $(\mu \mathrm{l})$ \\
\hline$f t s Z$ I & DNA & $50 \mathrm{ng} / \mu \mathrm{l}$ & $3.00 *$ \\
\hline \multirow[t]{2}{*}{$f t s \mathrm{Z}$ II } & $\mathrm{MgCl}_{2}$ & $50 \mathrm{mM}$ & $0.50 *$ \\
\hline & DNA & $50 \mathrm{ng} / \mu \mathrm{l}$ & 3.00 \\
\hline \multirow[t]{3}{*}{$f t s Z$ III } & Primer F & $8 \mu \mathrm{M}^{*}$ & 0.50 \\
\hline & Primer R & $8 \mu \mathrm{M}^{*}$ & 0.50 \\
\hline & DNA & $50 \mathrm{ng} / \mu \mathrm{l}$ & $3.00 *$ \\
\hline \multirow[t]{4}{*}{ ftsZ IV } & $\mathrm{MgCl}_{2}$ & $50 \mathrm{mM}$ & $0.50 *$ \\
\hline & Primer F & $8 \mu \mathrm{M}^{*}$ & 0.50 \\
\hline & Primer R & $8 \mu \mathrm{M}^{*}$ & 0.50 \\
\hline & DNA & $50 \mathrm{ng} / \mu \mathrm{l}$ & 3.00 \\
\hline \multirow[t]{3}{*}{$f t s \mathrm{Z}$} & DNTP & $10 \mathrm{mM}$ & $0.50 *$ \\
\hline & $\mathrm{MgCl}_{2}$ & $50 \mathrm{mM}$ & $0.50 *$ \\
\hline & DNA & $50 \mathrm{ng} / \mu \mathrm{l}$ & $3.00 *$ \\
\hline \multirow[t]{5}{*}{$f t s \mathrm{Z}$ VI } & DNTP & $10 \mathrm{mM}$ & $0.50 *$ \\
\hline & $\mathrm{MgCl}_{2}$ & $50 \mathrm{mM}$ & $0.50 *$ \\
\hline & Primer F & $8 \mu \mathrm{M}^{*}$ & 0.50 \\
\hline & Primer R & $8 \mu \mathrm{M}^{*}$ & 0.50 \\
\hline & DNA & $50 \mathrm{ng} / \mu \mathrm{l}$ & $3.00 *$ \\
\hline \multirow[t]{2}{*}{$f t s \mathrm{Z}$ VII } & Taq DNA polymerase & 1 unit & $0.25 *$ \\
\hline & DNA & $50 \mathrm{ng} / \mu \mathrm{l}$ & 3.00 \\
\hline ftsZ VIII & Fresh DNA* & $50 \mathrm{ng} / \mu \mathrm{l}$ & 5.00 \\
\hline
\end{tabular}

*Alteration in PCR conditions (reagent concentration and/or volume).

Table 3. Efficiency of the ftsZ primer in detecting Wolbachia in Anastrepha samples using the altered protocols (ftsZ I-VIII) described in Table 2.

\begin{tabular}{ccccccc}
\hline \multirow{2}{*}{ Protocols } & \multicolumn{5}{c}{ Samples } & Total \\
\cline { 2 - 5 } & $\boldsymbol{A . s p . 1}(\mathbf{J a c})$ & $\boldsymbol{A . s p . 1}(\mathbf{S N})$ & $\boldsymbol{A . s p . 2}$ (Cag) & $\boldsymbol{A . s p . 3 ~ ( C a g ) ~}$ & \\
\hline$f t s Z$ I & $27 \%$ & - & - & - & - & $4 \%$ \\
$f t s Z$ II & - & - & - & - & - \\
$f t s Z$ III & - & - & - & - & - \\
$f t s Z$ IV & - & - & - & - & - \\
$f t s Z$ V & - & - & - & - & - \\
$f t s Z$ VI & - & $42.1 \%$ & $40.0 \%$ & $45.0 \%$ & $44.9 \%$ \\
$f t s Z$ VII & $63.3 \%$ & - & $\mathrm{n}$ & $\mathrm{n}$ & $20.2 \%$ \\
$f t s Z$ VIII & $55 \%$ & &
\end{tabular}

Collection sites: Jac - Jacareí; SN - Serra Negra; Cag - Caraguatatuba.

(-): absence of fragment.

(n): not tested with the protocol indicated. 
No Wolbachia were detected with protocols ftsZ II, III, IV, $\mathrm{V}$ and VI (Table 2), indicating that the alterations incorporated in these reactions did not improve the efficiency of detection. In reaction ftsZ VII in which the volume of Taq DNA polymerase was changed and the number of cycles was increased from 35 to 40 (in order to enhance the number of DNA fragments) (Table 2), Wolbachia was detected in $44.9 \%$ of the samples (Table 3). However, this protocol showed poor reproducibility for the same sample analyzed at different times (Figure 2A, B). Similar findings were reported by Jeyaprakash and Hoy (9) for other arthropod species and these authors proposed that DNA present in the reaction could interfere with Taq DNA polymerase activity to generate false negatives.

Werren and Windsor (30) observed that the quality of
DNA was a determinant factor in the successful detection of Wolbachia with the ftsZ primer and recommended that only newly extracted DNA be used for the PCR, i.e., one should avoid using DNA stored at $-20^{\circ} \mathrm{C}$. To examine the influence of DNA quality on the detection of Wolbachia with the ftsZ primer we extracted DNA from Anastrepha sp.1 (Jacareí and Serra Negra) and used it in protocol VIII, along with the wsp and $16 \mathrm{~S}$ rDNA primers. In these conditions, Walbachia was detected in $20.2 \%$ of the samples screened with the fts $\mathrm{Z}$ primer (Table 3), whereas all of the samples tested with the wsp and $16 \mathrm{~S}$ rDNA primers were positive for the bacteria. These findings confirm the low sensitivity of the ftsZ primer in detecting Wolbachia in Anastrepha, despite the alterations in the extraction and amplification protocols.

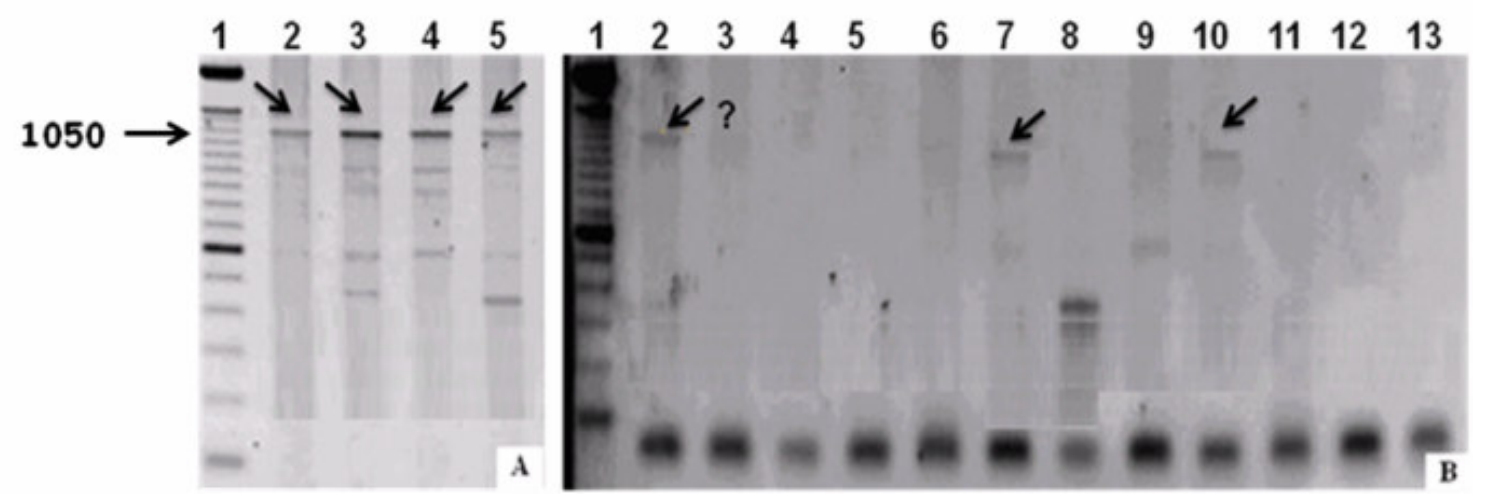

Figure 2. Electrophoresis of Anastrepha sp. 1 (Jacareí) samples in $1 \%$ agarose gels containing $1 \%$ ethidium bromide, after amplification with the primers ftsZ (A) and ftsZ (B). The Anastrepha sp.1 samples are in lanes 2-5 in (A) and lanes 2-13 in (B). Lane 1 - $100 \mathrm{bp}$ ladder. Arrows indicate the presence of fragments. ?= presence of fragment in column B3 uncertain.

Together, the results of this study indicate that the most efficient way of detecting Wolbachia in Anastrepha, and of identifying the relevant supergroup and making phylogenetic inferences, is through the combined use of $16 \mathrm{~S}$ rDNA and wsp primers. The $16 \mathrm{~S}$ rDNA primer can be used by itself to detect Wolbachia and identify supergroups. However, since this primer is for preserved gene it is inappropriate for phylogenetic and population analyses. This limitation can be overcome by concomitant use of the wsp primer, which by itself is inappropriate for identifying Wolbachia supergroups A and B. The variability of wsp makes primers of this gene particularly useful for phylogenetic and population analyses.

\section{ACKNOWLEDGMENTS}

This work was supported by Fundação de Amparo à Pesquisa do Estado de São Paulo (FAPESP) and 
Coordenadoria de Aperfeiçoamento de Pessoal de Nível Superior (CAPES).

\section{REFERENCES}

1. Bourtzis, K. (2008). Wolbachia-based technologies for insect pest population control. Adv. Exp. Med. Biol. 627, 104-113.

2. Braig, H.R.; Zhou, W.; Dobson, S.; O’Neil, S.L. (1998). Cloning and characterization of the gene encoding the major surface protein of the bacterial endosymbiont Wolbachia. J. Bacteriol. 180, 2373-2378.

3. Coscrato, V.E. (2006). Detecção e filogenia da bactéria endossimbionte Wolbachia em espécies de moscas-das-frutas do gênero Anastrepha e Ceratitis (Diptera: Tephritidae). Botucatu - S.P., Brazil. 144 p. (PhD Dissertation. Instituto de Biociências. UNESP).

4. Coscrato, V.E.; Braz, A.S.; Perondini, A.L.P.; Selivon, D.; Marino, C.L. (2009). Wolbachia in Anastrepha fruit flies (Diptera: Tephritidae). Curr. Microbiol. 59, 295-301.

5. Duarte, A.L. and Malavasi, A. (2000). Tratamentos quarentenários. In: Malavasi, A. and Zucchi, R.A. (eds). Moscas-das-frutas de importância econômica no Brasil (conhecimento básico e aplicado). FAPESP-Holos, Ribeirão Preto, Brazil, p.187-192.

6. Holden, P.R.; Brookfield, J.F.Y.; Jones, P. (1993). Cloning and characterization of an $f t s Z$ homologue from a bacterial symbiont of Drosophila melanogaster. Mol. Gen. Genet. 240, 213-220.

7. Hong, X.Y.; Gotoh, T.; Noda, H. (2002). Sensitivity comparison of PCR primers for detecting Wolbachia in spider mites. Appl. Entomol. Zool. 37, 379-383.

8. Jamnongluk, W.; Kittayapong, P.; Baimai, V.; O'Neill. S.L. (2002) Wolbachia infections of tephritid fruit flies: molecular evidence for five distinct strains in a single host species. Curr. Microbiol. 45, 255-260.

9. Jeyaprakash, A. and Hoy, M.A. (2000). Long PCR improves Wolbachia DNA amplification: wsp sequences found in $76 \%$ of sixty-three arthropod species. Insect Mol. Biol. 9, 393-405.

10. Jowett, T. (1986). Preparation of nucleic acids. In: Roberts, D.B. (ed). Drosophila: a practical approach. Oxford University Press, Oxford. p. 275-286.

11. Kittayapong, P.; Milne, J.R.; Tigvattananont, S.; Baimai, V. (2000) Distribution of the reproduction-modifying bacteria, Wolbachia, in natural populations of tephritid fruit flies in Thailand. Sci. Asia. 26, 93103.

12. Lo, N.; Casiraghi, M.; Salati, E.; Bazzocchi, C.; Bandi, C. (2002). How many Wolbachia supergroups exist? Mol. Biol. Evol. 19, 341-346.

13. Lo, N.; Paraskevopoulos, C.; Bourtzis, K.; O'Neill, S.L.; Werren, J.H.;
Bordenstein, S.R.; Bandi, C. (2007). Taxonomic status of the intracellular bacterium Wolbachia pipientis. Int. J. Syst. Evol. Microbiol. 57, 654-657.

14. Lukenhaus, J.F. (1990). Regulation of cell division in E. coli. Trends Genet. 6, 22-25.

15. Malavasi, A.; Zucchi, R.A.; Sugayama, R.L. (2000). Biogeografia, In: Malavasi, A. and Zucchi, R.A. (eds). Moscas-das-frutas de importância econômica no Brasil (conhecimento básico e aplicado). FAPESP-Holos, Ribeirão Preto, Brazil, p. 93-98.

16. Marcon, H.S. (2009). Identificação da bactéria endossimbionte Wolbachia em populações de moscas-das-frutas do complexo Anastrepha fraterculus (Diptera: Tephritidae). Botucatu - S.P., Brazil. 110 p. (MSc Dissertation. Instituto de Biociências. UNESP).

17. Mascarenhas, R.O. (2007). Endossimbionte Wolbachia em moscas-dasfrustas do gênero Anastrepha (Thephritidae) e em vespas parasitóides (Braconidae) associadas. São Paulo - S.P., Brazil. 80 p. (MSc Dissertation. Instituto de Biociências. USP).

18. O’Neil, S.L.; Giordano, R.; Colbert, A.M.; Karr, T.L.; Robertson, H.M. (1992). 16S rRNA phylogenetic analysis of the bacterial endosymbionts associated with cytoplasmic incompatibility in insects. Proc. Natl. Acad. Sci. USA 89, 2699-2702.

19. O'Neil, S.L.; Hoffmann, A.A.; Werren, J.H. (1997). Influential passengers: inherited microorganisms and arthropod reproduction. Oxford University Press, New York, 214 p.

20. Riegler, M. and Stauffer, C. 2002. Wolbachia infections and superinfections in cytoplasmically incompatible populations of the European cherry fruit fly Rhagoletis cerasi (Diptera, Tephritidae). Mol. Ecol. 11, 2425-2434.

21. Rocha, L.S.; Mascarenhas, R.O.; Perondini, A.L.P.; Selivon, D. (2005). Occurrence of Wolbachia in Brazilian samples of Ceratitis capitata (Wiedmann) (Diptera: Tephritidae). Neotrop. Entomol. 34, 1013-1015.

22. Ruang-Areerate, T.; Kittayapong, P.; Baimai, V.; O’Neill, S.L. (2003). Molecular phylogeny of Wolbachia endosymbionts in Southeast Asian mosquitoes (Diptera: Culicidae) based on wsp gene sequences. J. Med. Entomol. 40, 1-5.

23. Selivon, D.; Perondini, A.L.P.; Ribeiro, A.F.; Marino, C.L.; Lima, M.M.A.; Coscrato, V.E. (2002). Wolbachia endosymbiont in a species of Anastrepha fraterculus complex (Diptera: Tephritidae). Invertebr. Reprod. Dev. 42, 121-127.

24. Stouthamer, R.; Breewer, J.A.J.; Hurst, G.D.D. (1999). Wolbachia pipientis: microbial manipulator of arthropod reproduction. Annu. Rev. Microbiol. 53, 71-102.

25. Sun, X.; Li, Z.H.; Liang, G.Q.; Chen, H.J.; Chen, N.Z. (2004). Detection of Wolbachia in Bactrocera (B.) dorsalis (Hendel) of China. Plant Quarant. 18, 321-323. 
26. Vavre, F.; Fleury, F.; Lepetit, D.; Fouillet, P.; Bouletreau, M. (1999). Phylogenetic evidence for horizontal transmission of Wolbachia in hostparasitoid associations. Mol. Biol. Evol. 16, 1711-1723.

27. Werren, J.H.; Windsor, D.; Guo, L.R. (1995a). Distribution of Wolbachia among neotropical arthropods. Proc. R. Soc. Lond. Ser. B: Biol. Sci. 262, 197-204.

28. Werren, J.H.; Zhang, W.; Guo, L.R. (1995b). Evolution and phylogeny of Wolbachia: reproductive parasites of arthropods. Proc. R. Soc. Lond. Ser. B: Biol. Sci. 261, 55-63.

29. Werren, J.H. (1997). Biology of Wolbachia. Annu. Rev. Entomol. 42,
587-609.

30. Werren, J.H., and Windsor, D.M. (2000). Wolbachia infection frequencies in insects: evidence of a global equilibrium? Proc. R. Soc. Lond. Ser. B: Biol. Sci. 267, 1277-1285.

31. Xiao-Yue, H.; Gotoh, T.; Noda, H. (2002). Sensitivity comparison of PCR primers for detecting Wolbachia in spider mites. Appl. Entomol. Zool. 37, 379-383.

32. Zhou, W.; Rousset, F.; O'Neill, S.L. (1998). Phylogeny and PCR based classification of Wolbachia strains using wsp gene sequences. Proc. R. Soc. Lond. Ser. B: Biol. Sci. 265, 509-515. 